\title{
MARKET CHARACTERISTICS AND CLUSTER ANALYSIS OF NON-WOOD FOREST PRODUCTS
}

\section{TRŽIŠNE KARAKTERISTIKE I KLASTER ANALIZA NEDRVNIH ŠUMSKIH PROIZVODA}

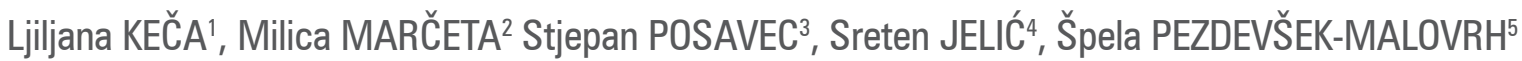

\begin{abstract}
Summary
The share of small and medium-sized enterprises (SMEs) is largely present in forestry, especially in the segment related to non-wood forest products (NWFPs) in Europe. They are also a dominant category in entrepreneurship in Serbia. Therefore, the subjects of this research were the companies operating in the sector of NWFPs, within specific statistical regions of Serbia. The database of SMEs was obtained from 119 SMEs and the share of surveyed SMEs was $81.5 \%$. The main research method was two-step cluster analysis. Questionnaire was used for the purpose of the research. The aim of the research was to identify clusters in order to establish similarities within the defined clusters and the differences among them. Spatial distribution of specific categories of NWFPs in nature (mushrooms, medicinal and aromatic plants, honey and wild berries), contributed to the portfolio of the companies. This largely influenced clusters that are created by categories of products that are typical for certain statistical regions in Serbia.
\end{abstract}

KEY WORDS: cluster analysis, forest products, spacial distribution, Serbia, market.

\section{INTRODUCTION}

\section{UVOD}

Research related to small and medium-sized enterprises (SMEs) and their clustering was intensified in the past decade. Accordingly, many authors used cluster analysis based on different variables that were of importance for their research (Setyaningsih 2012). The transition to a market economy has resulted in a large number of SMEs (Audretsch and Thurik 2000; Jaouen and Lasch 2015) and they represent the dominant category of entrepreneurship in Serbia. At the same time, they are the bearers of economic activities at the broader European level. Even in the developed European economies, such as Britain, over $99 \%$ of compa- nies are categorised as SMEs (Brinkley 2008). On the other hand, in transitional and developing countries SMEs play a very important role in such economic systems (Hunjra 2011; Kraja and Osmani 2013; Eniola and Ektebang 2014). They are primarily enterprises involved in the field of trade. The increase in the number of SMEs can significantly contribute to the strengthening of the economy (Kurniawati and Yuliando 2015). If one considers the forestry sector in Serbia, primarily focused on gathering, processing and selling of non-wood forest products (NWFPs) (Keča et al. 2013), small family businesses frequently employ less than 10 people. According to their product orientation, they are primarily focused on purchase, processing and selling of medicinal plants, mushrooms and berries. According to sta-

\footnotetext{
1 Ljiljana Keča, Associate Professor at University of Belgrade, Faculty of Forestry, Belgrade, e-mail: lijljana.keca@sfb.bg.ac.rs

${ }^{2}$ Milica Marčeta, PhD student, University of Belgrade, Faculty of Forestry, Belgrade, e-mail: milica.marceta@sfb.bg.ac.rs

${ }^{3}$ Stjepan Posavec, Associate Professor at University of Zagreb, Faculty of Forestry, Zagreb, e-mail: sposavec@sumfak.hr

${ }^{4}$ Sreten Jelić, Associate Professor at University of Belgrade, Faculty of Agriculture, e-mail: sjelic@agrif.bg.ac.rs

${ }_{5}^{5}$ Špela Pezdevšek-Malovrh, Assistant Professor at University of Ljubljana, Biotechnical Faculty, e-mail: spela.pezdevsekMalovrh@bf.uni-lj.si
} 
tistical regions of the country, the dominance of certain categories of NWFPs was recognised and hence the aim of the research was clustering of the analysed companies based on selected characteristics relevant for the research. The purpose of the research was to identify clusters, establish similarities within the defined clusters (Ferligoj 2003), and diagnose the differences among them. The subjects of the research were the companies operating in the sector of NWFPs within four statistical regions of Serbia.

According to the research of Innovation Entrepreneurship in Forestry in Central Europe (Rametsteiner et al. 2005), the forestry innovation system is active in the fields of technological and organisational innovations, and in the diffusion of specific pre-selected innovations. Typical areas of activity are mechanisation of forest work and the forming of forest owners' co-operations. With the exception of some selected topics - such as bio-energy or forest education - product and service innovations are rather disregarded. Specific support aimed at the development of new products and service innovations is practically missing (Rimmler et al. 2011; Posavec et al. 2011). Most of the non-wood products market is weak or underdeveloped, and its use is frequently unregulated due to which direct financial benefits for the owner cannot be exploited (Mavsar et al. 2008). The entire value chain from the ensurance of non-wood forest products in the forest, to the exploitation and recognition by the forest owners and users (Merlo and Paveri 1997) and improvements in forest management is considerably demanding (Pettenella et al. 2006; Posavec et al. 2010). It is influenced by both internal factors, such as ecosystem capacity and external factors, defined by interests and the requirements of the users and forest managers (Vuletić i et al. 2009). They are both influenced by polical and legal framework in the country.

\section{MATERIAL AND METHODS} MATERIJAL I METODE

In this study, the quantitative research approach was applied (Dul and Hak 2008; Lamnek 2005). Way of data collection was used as basic research technique (Lorenzini 2014). The questionnaire was intended for representatives of SMEs (i.e. owners, directors of enterprises, heads of the commercial sector, etc.). The questionnaire consisted of 46 open and closed-ended questions, divided in accordance with the analysed market elements such as: product, price and promotion. Basic database was obtained of SMEs. According to this database, 146 SMEs were registered in 2014 in Serbia and 119 SMEs were involved in purchasing, processing and sale of NWFPs which represented our sample*. The share of surveyed SMEs was $81.5 \%$. In order to make a compara-

\footnotetext{
* As the population was relatively small, sampling was not used in the research.
}

bility of SMEs, primarily related to the socio-economic and market aspects of NWFPs, SMEs were divided by statistical regions - Belgrade, Šumadija and Western Serbia, Southern and Eastern Serbia and Vojvodina. Data collection was undertaken in the period from 2010-2015.

Since the aim of this study was to develop a typology of SMEs involved in purchasing, processing and sale of NWFPs in Serbia, the answers to questions in Table 1 were used as the basis of the typology. Due to the mixture of continuous and categorical variables, the survey data was analysed using a SPSS two-step cluster analysis as described by Norušis (2008) and Shih et al. (2010). The first step of the procedure entailed forming preclusters. The procedure first assigned cases into small sub-clusters, then scanned the data and, based on a distance measure, the SPSS software algorithms determined whether the current case had to be merged with a previously formed precluster or a new precluster needed to be started. When preclustering was completed, all cases in the same preclusters were treated as a single entity. During the second step, the preclusters were clustered by using a hierarchical clustering algorithm.

The clustering algorithm was based on a log-likelihood distance measure because both continuous and categorical variables were used in the analysis. The distance between two clusters depended on the decrease in the log-likelihood when they were combined into a single cluster (Shih et al. 2010). The identified clusters were described concerning the region, the core products, export markets, the conditions under which the manufacturing process was performed, problems in business and payment terms using cross-tabulation. Finally, the validity of the independent variables to predict cluster membership was assessed using overall model quality (measure of cohesion and separation) and discriminant analysis described by Hair et al. (2006). All statistical analyses were carried out using SPSS 20 software (Corp. 2011).

Moreover, indexes of dynamics were used (Stojković 2001) to show the relative movement of the purchase and placement of NWFPs in time. For this purpose, the average annual growth rate was used (Bartlett 1993; Liargovas and Skandalis 2008) for certain categories of NWFPs. These growth rates were determined for the purchase of NWFPs, and for the placement on the domestic and foreign markets. The structure of dominant NWFPs category was presented for each cluster formed from the point of purchase, and placement on domestic and foreign markets. The questionnaire included the features concerning the business activities of the company related to the purchase, the placement on the domestic market and the export of NWFPs. The part about products included a series of questions about the purchase of raw materials, production, placement, plans for capacity expansion and assortment. The part related to the 
Table 1 Variables used as a basis of the typology Tablica 1 Korištene varijable kao osnova tipologije

Total amount of raw materials purchased annually $(\mathrm{t})$

a) mushrooms; b) medical and aromatic plants; c) honey; d) berries /

Ukupna količina sirovina kupljenih godišnje (t)

a) gljive; b) ljekovito i aromatično bilje; c) med; d) šumsko voće

Continuous variable /

Neprekidne varijable

Quantities of products in a raw state purchased for the period 2007-2014 (average in $t$ )

a) mushrooms; b) medical and aromatic plants; c) honey; d) berries /

Količine proizvoda u sirovom stanju kupljenih u razdoblju 2007-2014 (prosjek u t)

a) gljive; b) ljekovito i aromatično bilje; c) med; d) šumsko voće

Final products sold on the domestic market for the period 2007-2014 (average in $t$ )

a) mushrooms; b) medical and aromatic plants; c) honey; d) berries /

Finalni proizvodi koji se prodaju na domaćem tržištu za razdoblje 2007-2014 (prosjek u t)

a) gljive; b) ljekovito i aromatično bilje; c) med; d) šumsko voće

Final products sold on the foreign markets for the period 2007-2014 (average in $t$ )

a) mushrooms; b) medical and aromatic plants; c) honey; d) berries (

Finalni proizvodi koji se prodaju na inozemnom tržištu u razdoblju 2007-2014 (prosjek u t)

a) gljive;) b) ljekovito i aromatično bilje; c) med; d) šumsko voće

Extension of product range / Proširenje asortimana

Price competitiveness on the domestic market / Cijenovna konkurentnost na domaćem tržištu

Price competitiveness on the foreign markets / Cijenovna konkurentnosti na inozemnim tř̌ištima

Acceptance of standards related to NWFPs / Prihvaćanje standarda u vezi nedrvnih šumskih proizvoda
Continuous variable /

Neprekidne varijable

Continuous variable /

Neprekidne varijable

Continuous variable /

Neprekidne varijable

1 - Yes / Da; 2 - No / Ne

1 - Yes / Da; 2 - No / Ne

1 - Yes / Da; 2 - No / Ne

1 - Yes / Da; 2 - No / Ne prices addressed the issue of prices at which the products were sold both in the domestic and foreign markets, as well as the issue of the price competitiveness of enterprises. Questions regarding the promotion were about the use of promotional activities in the companies surveyed.

\section{RESULTS}

\section{REZULTATI}

\section{Basic information about the SMEs surveyed - Osnovne informacije 0 anketiranim malim i srednjim poduzeća}

According to the results of the survey, there were four main types of companies, and in particular, those focusing on the purchase, processing and sale of mushrooms, wild berries, medicinal and aromatic plants and honey which were considered as prevailing. The companies were mainly established during the period 1990-2005.

The number of companies surveyed in the statistical region of Šumadija and Western Serbia was 55 and in Southern and Eastern Serbia 31. In Vojvodina the number of companies surveyed was 24, while in Belgrade region there were only 9 companies. Considering the fact that Serbia has an unbalanced regional development (Jelić and Jovanović 2011), the companies surveyed were unevenly represented by statistical regions of Serbia.

Depending on the region, the dominant type of companies were those focusing on one type of NWFPs. Thus, in Voj- vodina the largest number of companies were focused on medicinal and aromatic plants. In Southern and Eastern Serbia the largest number of companies was oriented on berries, while in Šumadija and Western Serbia companies were largely focused on the purchasing, processing and sale of mushrooms (Figure 1).

\section{The results of the cluster analysis - Rezultati analize klastera}

Three groups of enterprises were identified in Serbia based on a preselected criteria algorithm (Schwarz Bayesian Criterion). They were identified and named according to their main distinguishing characteristics. The first group tended to score high on commercialisation of medicinal herbs and therefore was labelled 'Companies focusing on medicinal and aromatic plants'. The second group was identified as 'Companies focusing on berries' because of their quantity of purchase and placement on domestic market and export. The third group was labelled 'Companies focusing on mixed products', because of similar participation of mushrooms and berries into cluster.

The cluster analysis (Table 2) placed most SMEs in the cluster $3(73.9 \%)$. SMEs under the cluster 2 included $13.5 \%$ of enterprises, whereas the remaining $12.6 \%$ of the SMEs formed the cluster 1 .

The main products in the "Medicinal and aromatic plants" cluster were medicinal and aromatic plants (chamomile, mint, yarrow, St. John's wort etc.), while the „Berries” clu- 


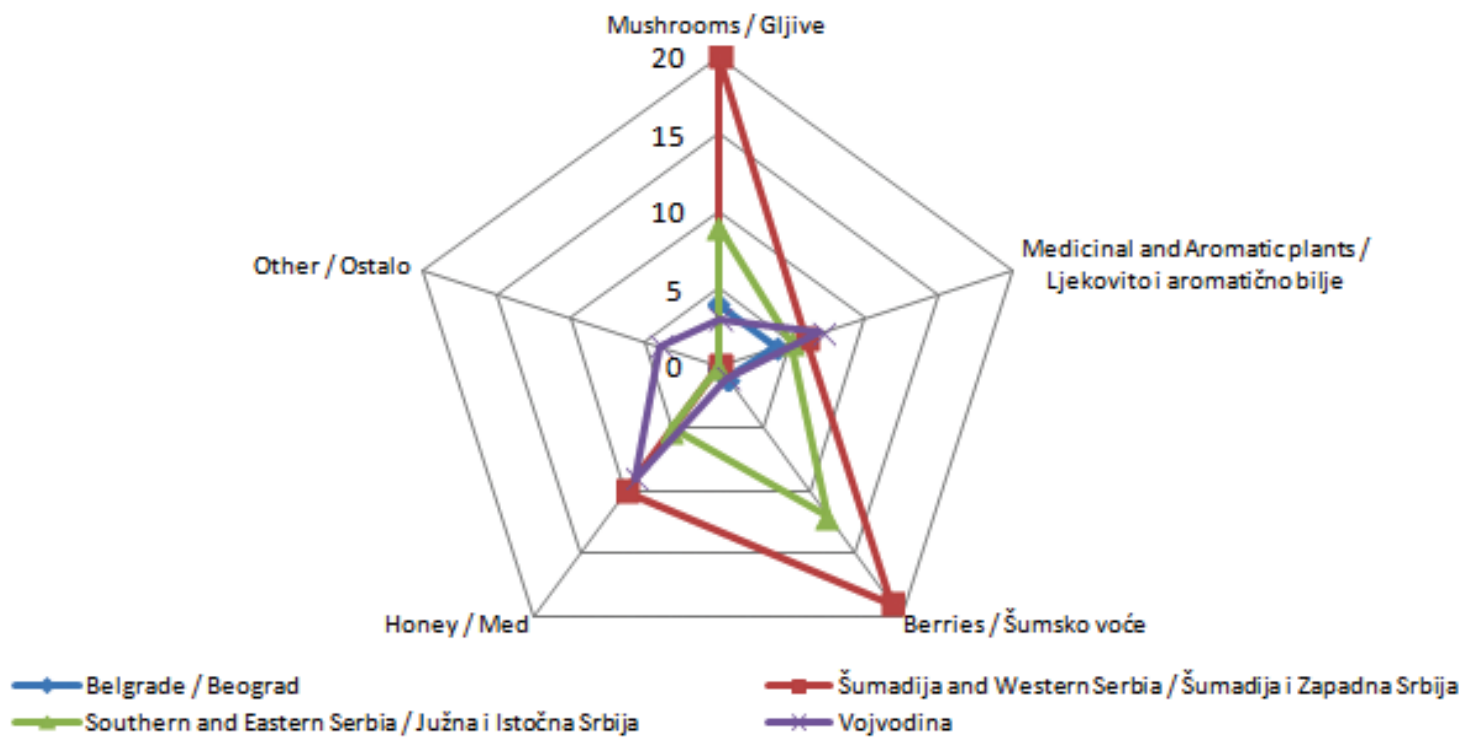

Figure 1 The number of enterprises by product category and region Slika 1 Broj poduzeća prema kategorijama proizvoda i regijama

ster focused primarily on berries (raspberries, blackberries, wild strawberries etc.), and the „Mixed products” cluster focused on mushrooms such as boletus (Boletus edulis) and chanterelle (Cantharellus cibarius) were prevailing and the following berries: raspberry (Rubus Idaeus), wild strawberries (Fragaria), Dog Rose (Rosa canina), blackberry (Vaccinium myrtillus). In the "Medicinal and aromatic plants" cluster the most used facilities were those for processing of medicinal and aromatic plants (45\%). In the „Berries" cluster those for beries (26.53\%), while in the "Mixed products" cluster the facilities for the processing of mushrooms were used in $8.77 \%$ and those for honey in $8.66 \%$ (Table 2).

At annually level the „Medicinal and aromatic plants” cluster purchased on average 149.4 tonnes of raw medicinal and aromatic plants, the „Berries” cluster purchased 291.5 tonnes of berries. Although into cluster "Berries” the companies had high quantity of purchasing of mushrooms on the annually level (160 tonnes), the more dominant category was berries. As result they were taken as primarly type of products in this cluster.

In the „Mix” cluster 37.2 tonnes of berries and 12.4 tonnes of mushrooms were purchased at the annually level.

In the cluster „Medicinal and aromatic plants“ average annual purchase was realized in medicinal and aromatic plants (44.3 t) in the cluster "Berries" the purchase of berries (223.4 t), while in the cluster "Mixed products" a balanced purchase of mushrooms and berries (10.1 t and $10.2 \mathrm{t}$ ) was recorded. As opposed to „Berries” and „Mixed products” clusters, where the purchase of berries was prevailing, the „Medicinal and aromatic plants" cluster companies are primarily involved in the purchase of medicinal and aromatic plants.
The placement on the domestic market in the cluster "Medicinal and Aromatic plants" was most accented in medicinal and aromatic plants (53.9 t), whilst in the other two clusters primarily berries ( $78 \mathrm{t}$ and $5 \mathrm{t}$ ) were recorded. Concerning the cluster „Medicinal and Aromatic plants” the most marketed products on the foreign market were medical and aromatic plants (47.2 t), with berries (93.3t) in the „Berries” cluster, and mushroms (1.48 $\mathrm{t}$ ) and berries (1.27 t) in the „Mixed products" cluster. The intention to expand the range of products was lacking in all the three clusters. 93\% of the enterprises included in the „Medicinal and Aromatic plants" cluster showed no intention of extending the product range. The percentage was slightly lower in the „Berries" cluster and stood at $80 \%$, whilst in the „Mixed products" cluster $56.1 \%$ of the companies showed no intention to expand their product portfolio. Concerning competitiveness in the „Medicinal and aromatic plants” cluster $71.4 \%$ of the companies pointed out the price competitiveness on the domestic market, whilst in the "Mixed products" cluster only $52.4 \%$ pointed out the price competitiveness on the domestic market. On the other hand, the „Berries” cluster emphasised that they were not price competitive on the domestic market (87\%). The differences between the attitudes to competitiveness on foreign markets were the most evident between the clusters „Medicinal and aromatic plants” and "Mixed products". In the „Medicinal and aromatic plants" cluster $78.6 \%$ of the companies highlighted the competitiveness of prices on the foreign market, while almost $90 \%$ of companies in the „Mixed products" cluster expressed the view that their prices were not competitive on the foreign market.

In the „Medicinal and aromatic plants" cluster the companies from the statistical region of Vojvodina prevailed, in 
Table 2 Percentages and mean values for variables describing clusters

Tablica 2 Postoci i srednje vrijednosti za varijable koje opisuju klastere

\begin{tabular}{|c|c|c|c|}
\hline \multirow{4}{*}{ Variable / Varijable } & Cluster 1 / Klaster 1 & Cluster 2 / Klaster 2 & Cluster 3 / Klaster 3 \\
\hline & $\begin{array}{l}\text { Medicinal and Aromatic Plants } \\
\text { / Ljekovito i aromatično bilje }\end{array}$ & $\begin{array}{l}\text { Berries / } \\
\text { Šumsko voće }\end{array}$ & $\begin{array}{c}\text { Mix / } \\
\text { Mješovito }\end{array}$ \\
\hline & $n=14$ & $n=15$ & $n=82$ \\
\hline & $(12.6 \%)$ & $(13.5 \%)$ & $(73.9 \%)$ \\
\hline \multicolumn{4}{|c|}{ Degree of utilization of installed capacity per year (\%) / Stupanj iskorištenja instalirane snage po godini (\%) } \\
\hline Mushrooms / Gljive & 4.29 & 20.67 & 8.77 \\
\hline $\begin{array}{l}\text { Medicinal and Aromatic Plants / } \\
\text { Ljekovito i aromatično bilje }\end{array}$ & 45.00 & 0.00 & 0.98 \\
\hline Honey / Med & 4.29 & 6.67 & 8.66 \\
\hline Berries / Šumsko voće & 22.50 & 26.53 & 8.04 \\
\hline \multicolumn{4}{|c|}{ Total amount of raw materials purchased on the annual level (t) / Ukupna količina sirovina kupljene na godišnjem nivou (t) } \\
\hline Mushrooms / Gljive & 3.57 & 160 & 12.44 \\
\hline $\begin{array}{l}\text { Medicinal and Aromatic Plants / } \\
\text { Ljekovito i aromatično bilje }\end{array}$ & 149.43 & 0 & 3.16 \\
\hline Honey / Med & 0.57 & 7.13 & 0.37 \\
\hline Berries / Šumsko voće & 59.07 & 291.47 & 37.24 \\
\hline
\end{tabular}

Average quantities of products in a raw state purchased for the period 2007-2014 (t) for all companies into cluster/

Prosječne količine proizvoda u sirovom stanju kupljene u razdoblju 2007-2014 (t) za sva poduzeća u klasteru

$\begin{array}{lccc}\text { Mushrooms / Gljive } & 1 & 63.87 & 10.16 \\ \text { Medicinal and Aromatic Plants / } & 44.29 & 0 & 0.67 \\ \text { Ljekovito i aromatično bilje } & 0.50 & 1.53 & 0.18 \\ \text { Honey / Med } & 4.50 & 223.40 & 10.11 \\ \text { Berries / Šumsko voće } & \end{array}$

Average final products sold on the domestic market for the period 2007-2014 (t) for all companies into cluster /

Prosječne količine finalnih proizvoda koji se prodaju na domaćem tržištu za razdoblje 2007-2014 (t) za sva poduzeća u klasteru

Mushrooms / Gljive

0,64

0

2.72

Medicinal and Aromatic Plants /

Ljekovito $i$ aromatično bilje

53.86

0

0.17

Honey / Med

0.21

18.80

0.61

Berries / Šumsko voće

6.79

78

5.02

Average quantity of final products sold on the foreign markets for the period 2007-2014 (t) for all companies into cluster Prosječne količine finalnih proizvoda koji se prodaju na stranim tržištima za razdoblje 2007-2014 (t) za sva poduzeća u klasteru

Mushrooms / Gljive

Medicinal and Aromatic Plants /

Ljekovito $i$ aromatično bilje

Honey / Med

Berries / Šumsko voće

Extension of product range /

Proširenje asortimana

Price competitiveness on the domestic

market / Cijenovna konkurentnost na

domaćem tržištu

Price competitiveness on the foreign

markets / Cijenovna konkurentnosti na stranim tržištima

$\begin{array}{ccc}0.29 & 74.27 & 1.48 \\ 47.21 & 0 & 0.06 \\ 0 & 0.93 & 0 \\ 28.21 & 93.33 & 1.27\end{array}$

No $(92.9 \%) / \mathrm{Ne}(92.9 \%)$

No $(80 \%) / \mathrm{Ne}(80 \%)$

No $(56.1 \%) / \mathrm{Ne}(56.1 \%)$

Yes $(71.4 \%)$ / Da (71.4\%)

No $(86.7 \%) / \mathrm{Ne}(86.7 \%)$

Yes (52.4\%) / Da (52.4\%)

Yes $(78.6 \%) / D a(78.6 \%)$

No $(53.3 \%) / \mathrm{Ne}(53.3 \%)$

No $(89 \%) / \mathrm{Ne}(89 \%)$ the „Berries” cluster companies from the area of Southern and Eastern Serbia were included, while the"Mixed products" cluster comprised of companies from the area of Šumadija and Western Serbia. In the „Medicinal and Aromatic plants" cluster export was balanced between WB countries and other parts of Europe. In the „Berries” cluster export was primarily oriented towards European countries (excluding WB countries) $87.5 \%$ and other parts of the world $12.5 \%$. In the „Mixed products” cluster export focu- sed exclusively on the European countries (excluding WB countries). From the aspect of the implementation of promotional activities in the "Medicinal and aromatic plants" cluster the most common promotion was via the Internet, followed by promotion through fairs (13.3\%), as well as in the „Berries” and „Mixed products” clusters where the main promotional tool were fairs both in Serbia and abroad. All the three clusters stressed that the main problem in business was the collection of receivables. The „Medicinal and 
Table 3 Business characteristics of the clusters

Tablica 3 Poslovne karakteristike klastera

\begin{tabular}{|c|c|c|c|}
\hline Variable / Varijable & Cluster 1 / Klaster 1 & Cluster 2 / Klaster 2 & Cluster 3 / Klaster 3 \\
\hline Region / Regija & Vojvodina / $(28.6 \%)$ & $\begin{array}{l}\text { Southern and Eastern Serbia (46.7\%) / } \\
\text { Južna i Istočna Srbija }(46.7 \%)\end{array}$ & $\begin{array}{l}\text { Šumadija and Westhern Serbia (52.4\%) } \\
\text { / Šumadija i Zapadna Srbija (52.4\%) }\end{array}$ \\
\hline $\begin{array}{l}\text { Export market / } \\
\text { Izvozna tržišta } \\
{ }^{*} \text { Western Balkan } \\
\text { countries }\end{array}$ & $\begin{array}{c}\text { WB* countries }(50 \%) / \\
\text { Zemlje zapadnog Balkana } \\
\text { Europe (except WB countries) (50\%) / } \\
\text { Europa izuzev zemalja Zapadnog } \\
\text { Balkana }(50 \%)\end{array}$ & $\begin{array}{c}\text { Europe (except WB countries) (87.5\%) / } \\
\text { Europa izuzev zemalja Zapadnog } \\
\text { Balkana (87.5\%) } \\
\text { World (12.5\%) / Svijet }\end{array}$ & $\begin{array}{c}\text { Europe (except WB countries) (100.0\%) } \\
\text { / Europa izuzev zemalja Zapadnog } \\
\text { Balkana (100\%) }\end{array}$ \\
\hline Promotion / Promocija & $\begin{array}{l}\text { Commercials (10\%) / Reklame (10\%) } \\
\text { Fairs (13.3\%) / Sajmovi (13.3\%) } \\
\text { Internet }(23.3 \%) \text { / Internet (23.3\%) }\end{array}$ & $\begin{array}{c}\text { Commercials (15\%) / Reklame (15\%) } \\
\text { Journals (15\%) / Časopisi (15\%) } \\
\text { Fairs (35\%) / Sajmovi }(35 \%) \\
\text { Internet }(30 \%) \text { / Internet }(30 \%)\end{array}$ & $\begin{array}{c}\text { Commercials (19.6\%) / } \\
\text { Reklame (19.6\%) } \\
\text { Fairs (31.6\%) / Sajmovi (31.6\%) } \\
\text { Internet (23.9\%) / Internet (23.9\%) }\end{array}$ \\
\hline $\begin{array}{l}\text { Problems in business / } \\
\text { Problemi u poslovanju }\end{array}$ & $\begin{array}{l}\text { Clients (7.1\%) / Klijenti (7.1\%) } \\
\text { Market (28.6\%) / Tržište (28.6\%) } \\
\text { Billing (64.3\%) / Naplata (64.3\%) }\end{array}$ & $\begin{array}{c}\text { Clients (7.1\%) Klijenti (7.1\%) } \\
\text { Market (42.9\%) / Tržište (42.9\%) } \\
\text { Billing (42.9\%) / Naplata (42.9\%) } \\
\text { Other (7.1\%) / Ostalo (7.1\%) }\end{array}$ & $\begin{array}{l}\text { Clients (14\%) / Klijenti (14\%) } \\
\text { Market (26.3\%) / Tržište (26.3\%) } \\
\text { Billing (57.9\%) / Naplata (57.9\%) } \\
\text { Other (1.8\%) / Ostalo (1.8\%) }\end{array}$ \\
\hline $\begin{array}{l}\text { Payment terms / } \\
\text { Oblici naplate }\end{array}$ & $\begin{array}{c}\text { Deferred payment (65\%) / } \\
\text { Odgođena isplata (65\%) } \\
\text { Advance payment (20\%) / Avans (20\%) }\end{array}$ & $\begin{array}{c}\text { On delivery }(36.8 \%) \text { / } \\
\text { Po dostavi }(36.8 \%) \\
\text { Deferred payment }(36.8 \%) \text { / } \\
\text { Odgođena isplata }(36.8 \%)\end{array}$ & $\begin{array}{c}\text { On delivery (44.2\%) / } \\
\text { Po dostavi (44.2\%) } \\
\text { Deferred payment (45.3\%) / } \\
\text { Odgođena isplata (45.3\%) }\end{array}$ \\
\hline
\end{tabular}

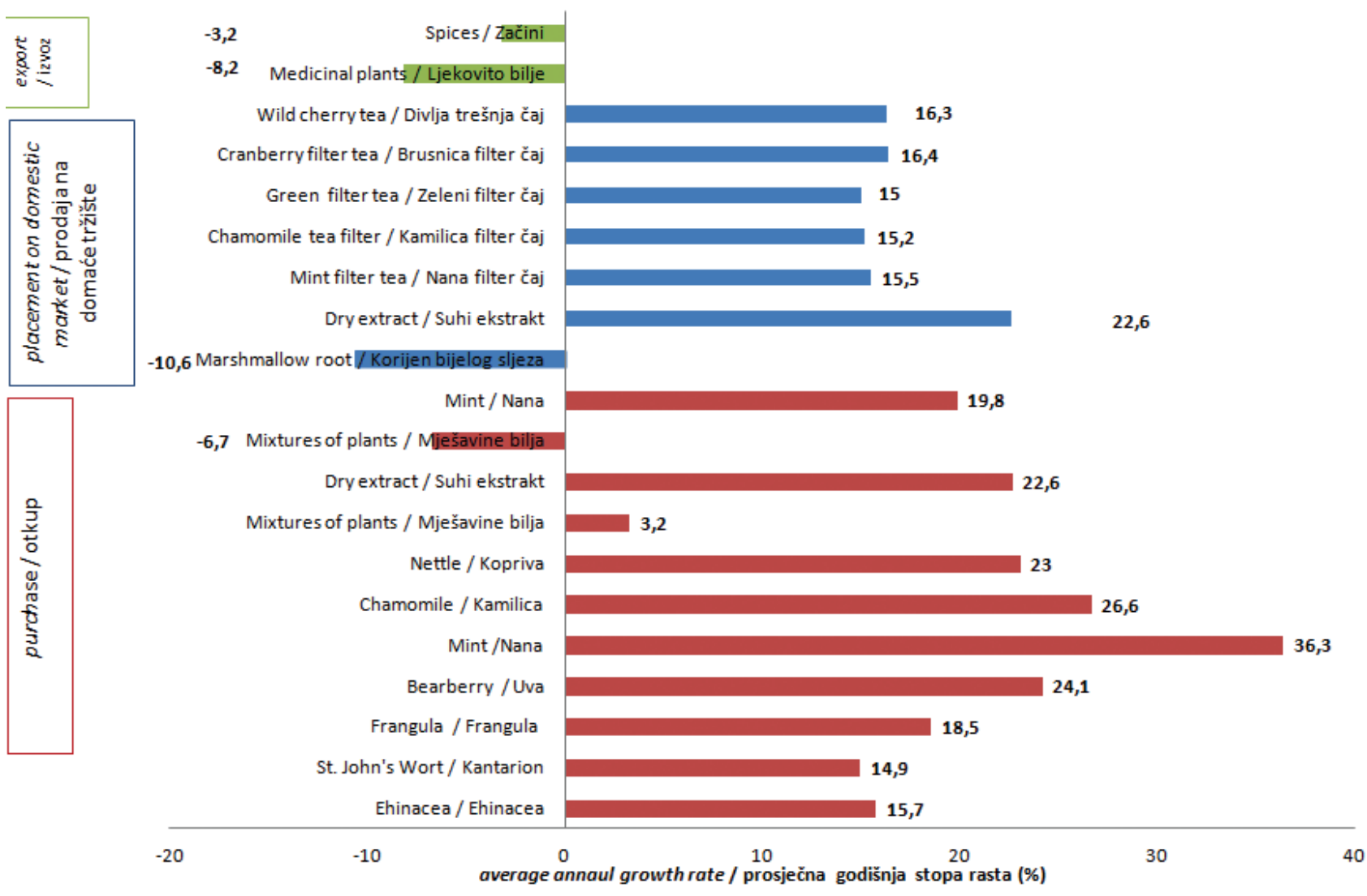

Figure 2 The average annual growth rate of purchase, placement on domestic market and export of medicinal plants Slika 2 Prosječna godišnja stopa rasta otkupa, prodaje na domaćem tržištu i izvoza ljekovitog bilja

Aromatic plants" cluster preferred deferred payments (65.0\%), while „Berries” and „Mix” cluster in addition to deferred payment also preferred collection on delivery.
Within the „Medicinal and Aromatic plants“ cluster the highest average annual growth rate was recorded in the purchase of mint (36.3\%) and chamomile (26.6\%). Concerning 


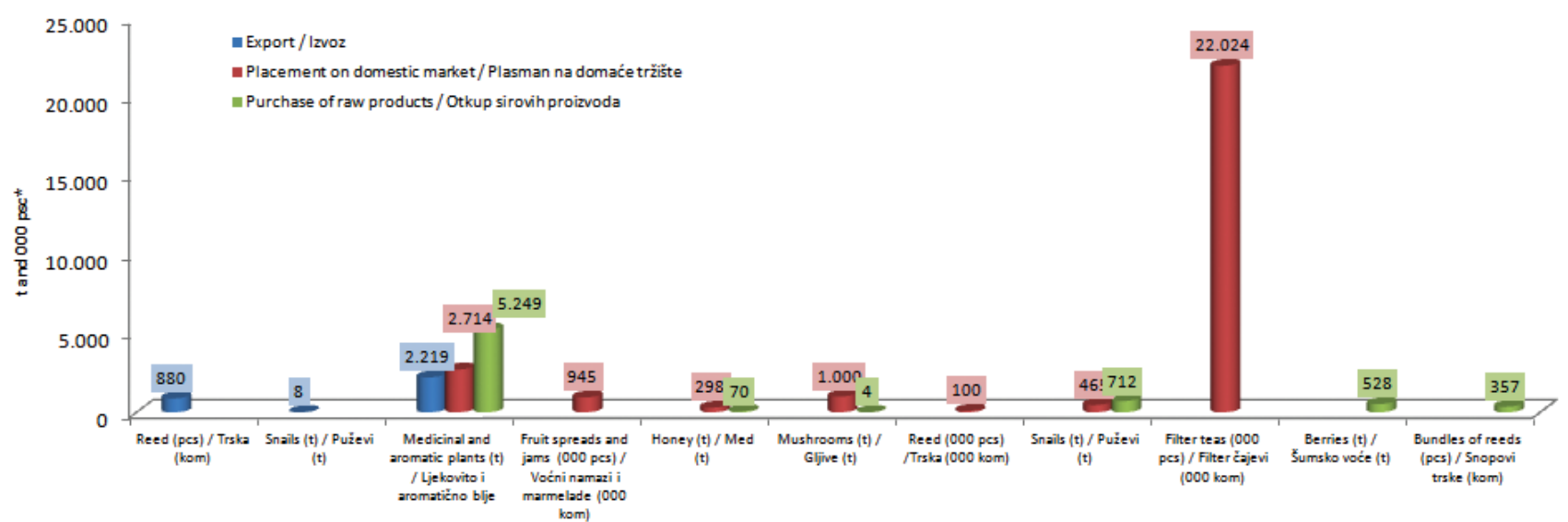

Figure 3 Total quantity of purchase, placement on domestic market and export of NWFPs in the statistical region of Vojvodina for the period 20072014

Slika 3 Ukupna količina otkupa, prodaje na domaće tržište i izvoza NDŠP u statističkoj regiji Vojvodina za razdoblje 2007-2014.

* some products are shown in 000 psc

the placement on the domestic market, the highest growth was recorded in relation to mint (19.8\%). Concerning exports, both the mixture of herbs and spices were declining (Figure 2).

In the statistical region of Vojvodina medicinal and aromatic plants and spices were prevailing, both in terms of the purchase of raw materials, and placement on the domestic market and exports (Figure 3). Compared with all the other analysed categories of NWFPs their share in the statistical region of Vojvodina was significantly higher. In the purchase and export, the most represented medicinal and aromatic plants were those ,in bulk". Filter bag teas were the most prevailing concerning the placement on the domestic market.

In the „Berries“ cluster, the highest average annual growth was recorded concerning the purchase of wild apples

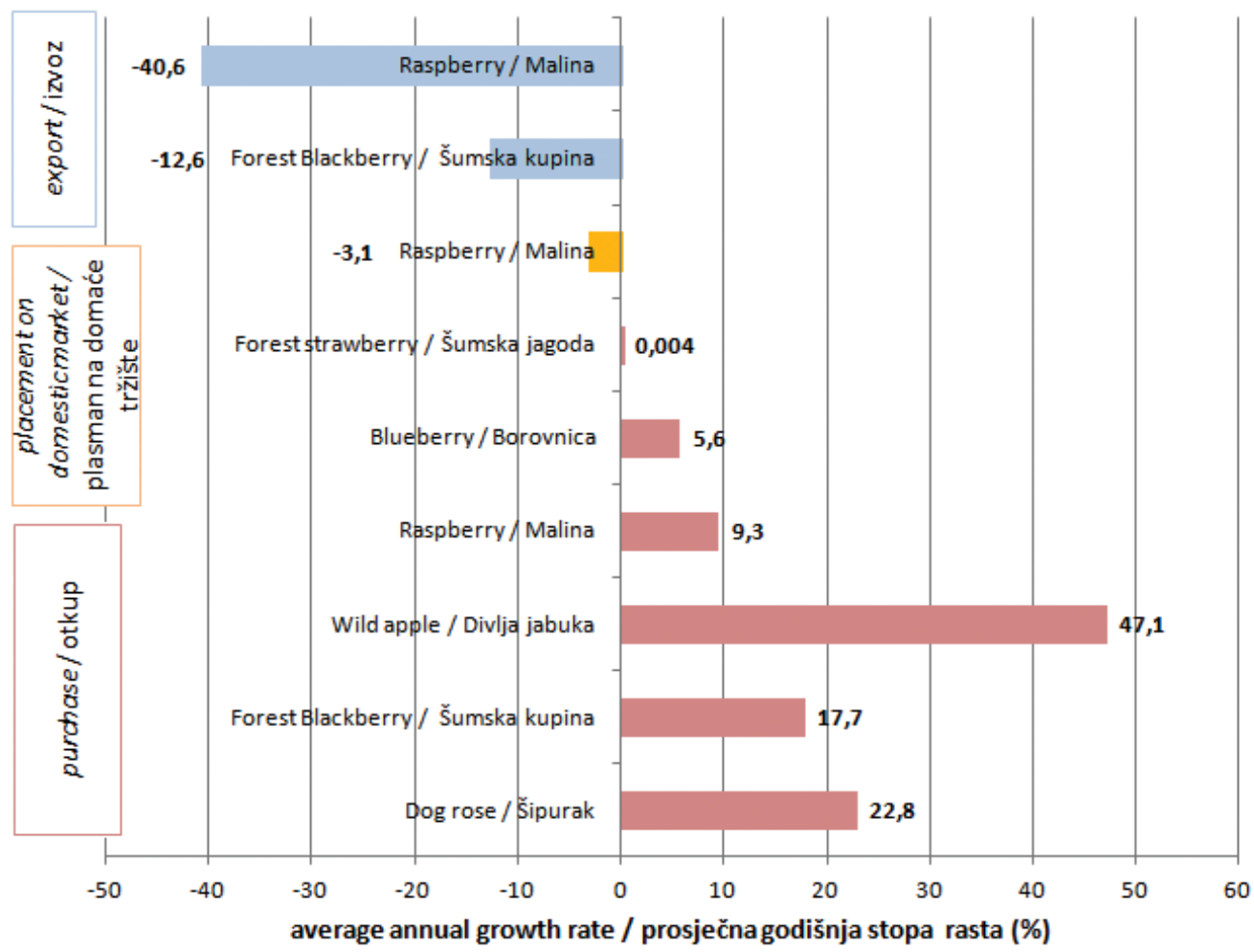

Figure 4 The average annual growth rate of purchase, placement on domestic market and export of berries in the „Berries" cluster Slika 4 Prosječna godišnja stopa rasta otkupa, prodaje na domaće tržište i izvoza šumskog voća u klasteru „Šumsko voće” 


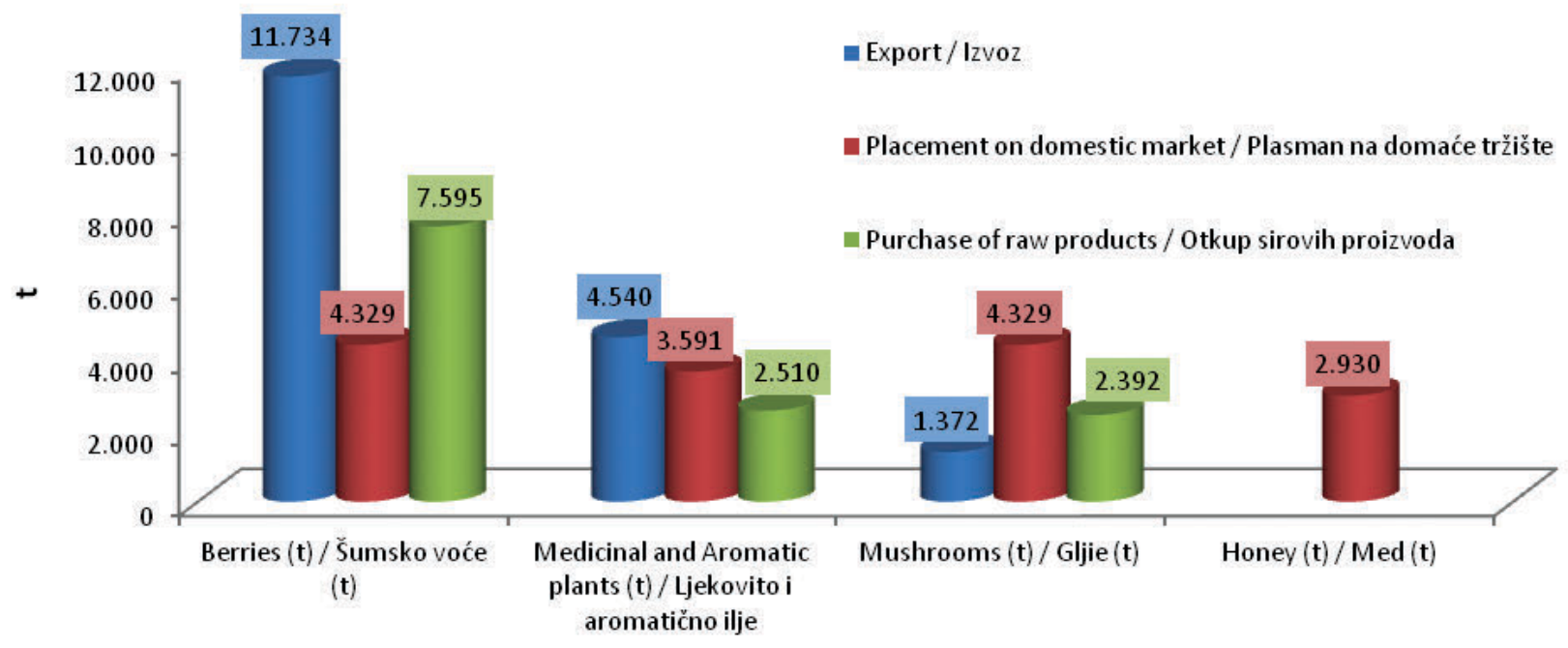

Figure 5 Total quantity of purchase, placement on domestic market and export of NWFPs in the statistical region of Southern and Eastern Serbia for the period 2007-2014

Slika 5 Ukupna količina otkupa, prodaje na domaće tržište i izvoza NDŠP u stastističkoj regiji Južna i Istočna Srbija za razdoblje 200.7-2014.

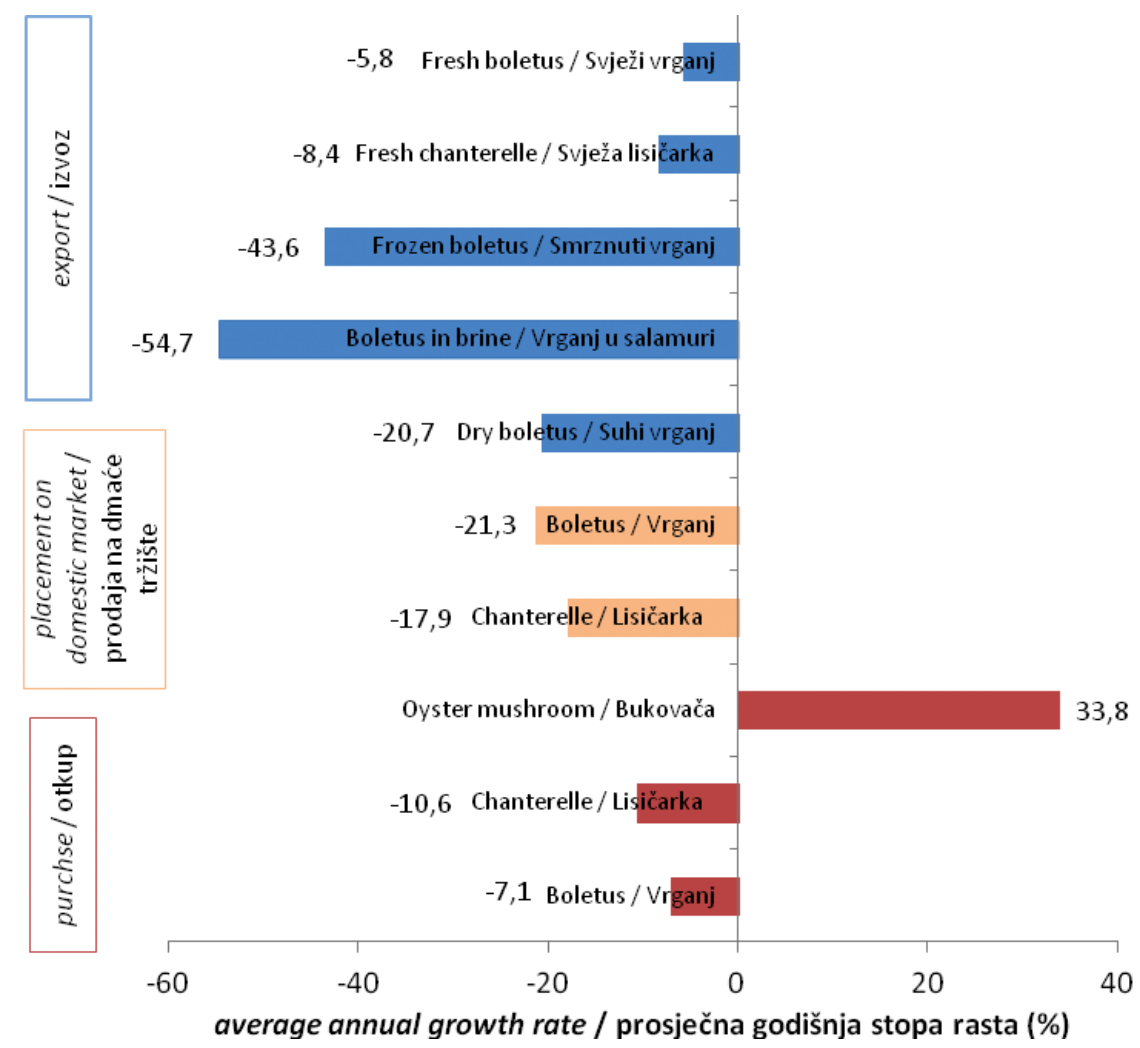

Figure 6 Average annual growth rate of purchase, placement on domestic market and export of mushrooms and berries in the "Mixed products" cluster

Slika 6 Prosječna godišnja stopa rasta otkupa, prodaje na domaće tržište i izvoza gljiva i šumskog voća u klasteru „Mješovito”

(47.1\%), whilst the placement of raspberries on the domestic market was in decline. On the other hand, raspberry exports recorded a significant drop of $40.6 \%$, as well as wild blackberries $12.6 \%$ (Figure 4).

In the statistical region of Southern and Eastern Serbia berries were dominant in all the activities: the purchase in raw form, the placement on the domestic market and export (Figure 5). Compared with other categories of NWFPs, berries recorded significantly higher quantities in both purchase and export.

In the „Mixed products" cluster positive growth rate was recorded in the purchase of oyster mushroom (33.8\%), 


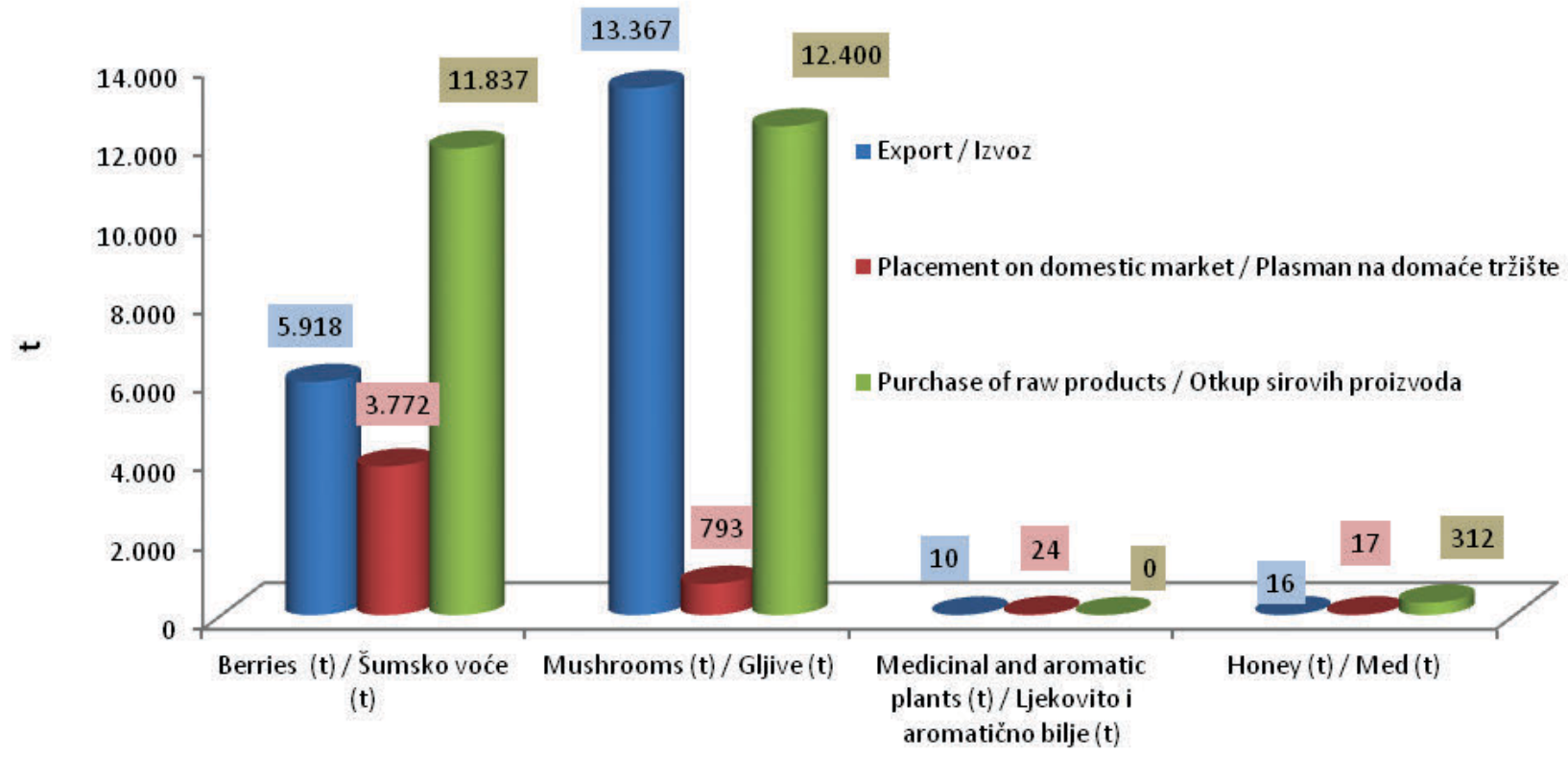

Figure 7 Total quantity of purchase, placement on domestic market and export of NWFPs in the statistical region of Šumadija and Western Serbia for the period 2007-2014

Slika 7 Ukupna količina otkupa, prodaje na domaće tržište i izvoza NDŠP u statističkoj regiji Šumadija i Zapadna Srbija za razdoblje 2007.-2014.

whilst negative growth rates were recorded for all the categories of products (mushrooms) (Figure 6). The increase in the average rate of growth was achieved in the purchase of a mixture of wild berries (15\%) and wild strawberries (13.2\%). The placement on domestic and foreign market showed positive growth rate in cases of dog rose (placement on the domestic market increased $12.2 \%$ ), whilst in the placement on the foreign market positive growth rate was recorded for raspberry $17.9 \%$ and blueberry $2.8 \%$ ).

Compared with other categories of NWFPs in the statistical region of Šumadija and Western Serbia in the segments of purchase and export mushrooms and berries were dominant categories of NWFPs, while berries were dominant in the placement on the domestic market (Figure 7).

\section{DISCUSSION}

\section{RASPRAVA}

Non-wood forest products present forest ecosystem value added and they could be a generator of development and innovative forest management. Consequently, forest owners should recognise economic effects of adaptive forest management in the future and ensure development of non-wood forest products and services in the market.

The analysed companies were established during the period between 1990 and 2005 and they were predominantly involved in the processing of mushrooms, berries and medicinal plants. The companies showed variations concerning the degree of product processing. Some of the companies surveyed sold products at a high level of finalisation, whilst the remaining companies had performed only primary processing (cleaning, sorting, measuring, etc.) prior to the product placement.

Seasonal workers were frequently hired in the summer and autumn to collect NWFPs, when the yields of product are the higest. The importance of SMEs is recognized at the global level, as they contribute to economic and social development (Sharman and Wadhawan 2009), and this is especially evident in companies involved in NWFPs. The reason is reflected in the fact that such companies do not require large initial investments and are often founded as small family companies. In addition to advantages such as flexibility, adaptability to change and innovation, SMEs are faced with obstacles (Beck and Demirguc-Kunt 2006) primarily occurring under the influence of globalisation, and due to a difficult access to foreign markets (Acs et al. 1997). In addition, the problems faced by the companies surveyed: the lack of adequate markets, difficulty in the collection of receivables and customer disloyalty and competition, as well as difficult soil conditions particularly in Central Serbia.

In Southeast Serbia, the largest purchase stations were: Boljevac, Aleksinac, Svrljig, Niš and Leskovac. Concerning Šumadija and Western Serbia the most important purchase stations were located in: Šabac, Valjevo, Loznica and Kruševac. In the region of Belgrade, the purchase of raw materials was carried out depending on the product from the entire territory of the Republic of Serbia, yet primarily from the Central, Eastern and Southeastern part of the country. Businesses in Central Serbia used on average $52.5 \%$ of installed generating capacity (Keča and Bogojević 2013), 61\% 
in Vojvodina (Keča et al. 2012), and in the statistical region of Belgrade, about $77.5 \%$ (Keča 2013).

Products that were most represented on the domestic and foreign markets were: boletus, raspberries, as well as different kinds of sweet and jam. The most important markets for medicinal and aromatic plants were Germany and Austria, and Germany is the most important market concerning honey and honey products.

Variables used in cluster analysis were selected based on previous theoretical and experiential knowledge of researchers (Soldić-Aleksić and Chroneos Krasavac 2009). The selection of variables in the research conducted was performed based on the relevance for cluster analysis of the company and thus for market research of NWFPs in Serbia. In this way three clusters were defined where each of them was focused on a specific category of NWFPs, in terms of purchase of raw products, placement on the domestic market and export.

It is important to highlight that each cluster belonged to a different statistical region. Moreover, different categories of NWFPs prevailed in each cluster. In addition to market advantages such as flexibility, adaptability to change and innovation, SMEs were faced with obstacles (Beck and Demirguc-Kunt 2006) which primarily occurred under the influence of globalisation, and due to a difficult access to foreign markets (Acs et al. 1997). Furthermore, the problems faced by the companies surveyed included the lack of adequate markets, difficulties in the collection of receivables and customer disloyalty and competition, as well as also difficult soil conditions particularly in Central Serbia and the issue of collection of receivables (Marčeta and Keča 2014).

\section{CONCLUSIONS}

\section{ZAKLJUČCI}

Out of the total 119 companies surveyed three clusters were formed. The largest number of companies surveyed was located in the statistical region Šumadija and Western Serbia (55 companies), and the smallest number of them was from the Statistical Region of Belgrade (9). The „Medicinal and Aromatic plants" cluster accounted for $73.9 \%$ of the companies surveyed and the largest were those focusing on the purchase, processing and marketing of medicinal and aromatic plants. This cluster was named „Medicinal and Aromatic plants" and these companies were mainly situated on the territory of Vojvodina. The "Berries" cluster consisted of $13.5 \%$ of the companies surveyed, and those were mainly focused on wild berries. This cluster was named „Berries” and primarily comprised of companies from the Southern and Eastern Serbia. The share of the „Mixed products” cluster stood at $12.6 \%$ amongst the companies surveyed and they were mainly focused on mushrooms and berries and were hence named „Mixed products" and most of them were located on the territory of Šumadija and Western Serbia.
According to average annual growth rate, concerning the purchase and sale of medicinal plants on the domestic market, the "Medicinal and Aromatic plants" cluster recorded strong growth, whilst exports showed stagnation. The „Berries" cluster shows a rise in the purchase of all the analysed types of berries and simultaneously a drop in their placement on the domestic market and export. The „Mixed products" cluster recorded negative growth rates in this category of products, both in the purchase and the sales in the domestic market and export. The exception was the oyster mushroom which achieved growth repurchase of 33\%.

Capacities in specific clusters were used intensively for the dominant categories of NWFPs. In the cluster „Medicinal and Aromatic plants" capacity utilisation for medicinal and aromatic plants was $45 \%$, whilst in the „Berries” cluster the utilisation of berries was $26.5 \%$. In the „Mixed products” cluster the utilization for mushrooms was $8.8 \%$.

In the „Medicinal and Aromatic plants” cluster 93\% of enterprises did not intend to expand the product range, in the „Berries” cluster the share of such companies stood at $80 \%$, whilst in the „Mixed products" cluster 56\% of the companies had no intention of expanding their product portfolio.

Price competitiveness on the domestic market in the „Medicinal and Aromatic plants" cluster was recorded in 71\% of the companies surveyed, while in the "Mixed products" cluster such companies accounted for $52 \%$. As opposed to to cluster 2 most companies emphasised that their prices were not competitive on the domestic market (87\%).

Concerning the aspect of price competitiveness on foreign markets the differences between the "Medicinal and Aromatic plants" cluster and the „Berries” cluster were the most significant.

Hence, in the „Medicinal and Aromatic plants" cluster 77\% of the companies surveyed highlighted the competitiveness of prices on the foreign market, while nearly $90 \%$ of the companies in the „Mixed products" cluster stated that their prices were not competitive on the foreign market. In the "Berries" cluster the companies noted the existence of price competitiveness on the foreign market.

Concerning the „Medicinal and Aromatic plants” cluster export to WB countries and to other parts of Europe was balanced (Germany, Italy, Austria, France, Switzerland, Poland, Slovenia, Hungary, etc.) (50:50\%). In case of the „Berries” cluster the export was primarily focused on European countries (excluding WB countries) $87.5: 12.5 \%$ and the remainder on diverse parts of the world. In the „Mixed products" cluster $100 \%$ of total exports were focused on the European countries (excluding WB countries).

Concerning the promotional activities in the cluster 1 the most common promotion was through the Internet, whilst in the „Berries” cluster and in the „Mushrooms” cluster the 
principal form of promotion was through trade fairs (domestic and foreign).

Following the analysis conducted, a conclusion can be reached that there was evident regional orientation towards a particular category of NWFPs. Hence, one can conclude that the closeness and availability of raw materials significantly affected the orientation of the company towards these specific product categories.

\section{REFERENCES}

\section{LITERATURA}

- Acs, Z., R., Morck, J.M., Shaver, B., Yeung, 1997: The Internationalization of Small and Medium-Sized Enterprises: A Policy Perspective, Small Business Economics, (9): 7-20, New York

- Audretsch, D.B., A.R., Thurik, 2000: Capitalism and Democracy in the $21^{\text {st }}$ Century: From the Managed to the Entrepreneurial Economy, Journal of Evolutionary Economics Vol. 10 (1-2): 17-34, Heidelberg

- Bartlett, A. A., 1993: Arithmetics of Growth: Methods of Calculation, Population and Environment, Vol. 14 (4), 359-387, Dordrecht

- Beck, T., A. Demirgüç-Kunt, 2006: Small and Medium-Sized Enterprises: Access to Finance as a Growth Constraint, Journal of Banking and Finance, 30, 2931-2943, Amsterdam

- Brinkley, I., 2008: Knowledge Economy and Enterprise, Work Foundation, London (43)

- Corp. I (2011) IBM SPSS Statistics for Windows. 20.0 edn. IBM Corp., Armon, NY.

- Dul, J., T., Hak, 2008: Case Study Methodology in Business Research. Butterworth-Heinemann, 302, Oxford

- Eniola, A. A., H., Ektebang, 2014: SME Firms Performance in Nigeria: Competitive Advantage and its Impact, International Journal of Research Studies in Management, Vol. 3 (2), 75-86, Malabon City

- Ferligoj, A., 2003: Recent Developments in Cluster Analysis, Telecommunication Systems, Vol. 1 (4): 205-220, New York

- Hunjra, A., 2011: Determinants of Business Success of Small and Medium Enterprises, International Journal of Business and Social Science Vol. 2 (18): 207-218

- Hair, J.F., W.C., Black, B.J., Babin, R.E., Anderson, R.L., Tatham, 2006: Multivariate Data analysis. 6th edn. Pearson Education Inc., New Jersey (497-587)

- Jaouen, A., F. Lasch, 2015: A new typology of micro-firm ownermanagers, International Small Business Journal, 33(4): 397-421

- Jelić, S., T., Jovanović, 2011: Ruralni razvoj u funkciji razvoja lokalnih zajednica. Ekonomika poljoprivrede, (58): 126-132

- Keča, Lj., 2013: Analiza marketing miks elemenata u poslovanju malih i srednjih preduzeća koja se bave NDŠP na području statističkog regiona Beograda, Glasnik Šumarskog fakulteta (108): 51-66, Beograd

- Keča, Lj., M., Bogojević, 2013: Komercijalizacija i marketing nedrvnih šumskih proizvoda na području centralne Srbije, Glasnik Šumarskog fakulteta, (107): 101-126, Beograd

- Keča, Lj., M., Marčeta, M., Bogojević, 2012: Komercijalizacija nedrvnih šumskih proizvoda na teritoriji AP Vojvodine, Glasnik Šumarskog fakulteta (105): 99-116, Beograd
- Keča Lj., N., Keča, M., Rekola, 2013: Value Chains of Serbian Non-Wood Forest Products, International Forestry Review 15(3): 315-335

- Kraja, B., E., Osmani, 2013: Competitive Advantage and its Impact in Small and Medium Enterprises (SMEs) (Case of Albania), European Scientific Journal, 9(16): 76-85

- Kurniawati, D., H., Yuliando, 2015: Productivity Improvement of Small Scale Medium Enterprises (SMEs) on Food Products: Case at Yogyakarta Province, Indonesia, Agriculture and Agricultural Science Procedia, (3): 189 - 194

- Lamnek, S. 2005: Qualitative Sozialforschung, Lehrbuch 4. Auflage, Beltz Verlag, Weihnhein, 808, Basel

- Liargovas, P.G., K.S., Skandalis, 2008: Motives and Marketing Strategies of Greek Companies Exporting to South-East European Markets, South-Eastern Europe Journal of Economics, Vol. 6 (2): $227-244$

- Lorenzini, E., 2014: Innovation and E-Commerce in Clusters of Small Firms: The Case of a Regional E-Marketplace, Local Economy, Vol. 29 (8): 771-794

- Marčeta M., LJ. Keča, 2014: Analysis of Sale of Non-Wood Forest Products from Northern Serbia on the Domestic and Foreign Markets, Baltic Forestry, 20(1): 115-130, Kaunas

- Mavsar, R., S., Ramčilović, M., Palahí, G. Weiss, E., Rametsteiner, S., Tykkä, R., Apeldoorn, J. Vreke, M., Wijk, G., Janse, 2008: Study on the Development and Marketing of Non-Market Forest Products and Services (dostupno na http://ec.europa.eu/ agriculture/analysis/external/forest_products/annexes_en.pdf (posjećeno 20.05.2016.)

- Merlo, M. and Paveri, M., 1997: Formation and Implementation of Forest Policies: a Focus on the Policy tools Mix. Special Paper prepared for Section G, Proceedings of the XI World Forestry Congress, volume (5): 233-254, Antalya

- Norušis, M., 2008: SPSS 16.0 Statistical Procedures Companion, 2nd edn. Prentice Hall, Upper Saddle River

- Posavec, S., J., Franjić, Ž., Škvorc, M., Lovrić, 2010: Koliko cijenimo socio-ekološke funkcije Šuma, U: M. Plenković (ur.), Društvo i tehnologija 2010, Hrvatsko komunikološko društvo, Zadar, dostupno na: http://bib.irb.hr/datoteka/504350.Posavec_ rad_DIT2010_Zadarverzij_akoja_je_upisana_u_crosbi1.doc (posjećeno 20.05.2016).

- Posavec, S., M., Šporčić, M., D., Antonić, K., Beljan, 2011: Innovation Fostering - Key Factor of Development in Croatian Forestry (Poticanje inovacija - ključ razvoja u hrvatskom šumarstvu), Šumarski list: znanstveno-stručno i staleško glasilo Hrvatskoga šumarskog društva, (5-6): 243-256, Zagreb

- Pettenella, D., Ciccarese, L., Dragoi, S., Hegedus, A., Hingston, A., Klöhn, S., Matilainen, A., Posavec, S., Thorfinnsson, T., 2006: NWFP\&S Marketing: Lessons Learned From Case Studies In Europe in Niskanen, A. (ed.). Issues affecting enterprise development in the forest sector in Europe. University of Joensuu, Faculty of Forestry, Research Notes 169. 406, Joensuu

- Rametsteiner, E., G., Weiss, G., K., Kubeczko, 2005: Innovation and Entrepreneurship in

- Forestry in Central Europe.Research report 19. Brill \& European Forest Institute, 179, Leiden (NL) \& Joensuu

- Rimmler, T., R., Coppock, R., Oberwimmer, A., Pirc, S., Posavec, G., Weiss, 2011: How to Support Firm Competitiveness in Timber Industries? Clusters as Policy Means in Four European Countries, Innovation in Forestry, 101-117 Cambrige 
- Setyaningsih, S., 2012: Using Cluster Analysis Study to Examine the Successful Performance 6 in Indonesia. Procedia Economics and Finance (4): 286-298

- Sharma, M., P., Wadhawan, 2009: A Cluster Analysis Study of Small and Medium Enterprises, The IUP Journal of Management Research, Vol. 8 (10): 7-23

- Shih, M. Y., Jheng, J. W., \& Lai, L. F., 2010: A two-step method for clustering mixed categroical and numeric data. ????, 13(1): $11-19$
- Soldić-Aleksić, J., B., Chroneos-Krasavac, 2009: Kvantitativne tehnike u istraživanju tržišta. Primena SPSS računarskog paketa. Centar za izdavačku delatnost, Ekonomski fakultet, 261, Beograd

- Stojković, M. 2001: Statistika, Ekonomski fakultet Subotica, Univerzitet u Novom Sadu, 942-987, Subotica

- Vuletić D., S. Krajter, M. Mrazek, A. Ćorić, 2009: Nedrvni šumski proizvodi i usluge - koristimo li ih dovoljno? Šumarski list 3-4, CXXXIII, 175-184, Zagreb

\section{Sažetak}

Dosadašnja istraživanja potvrđuju da lokalna, regionalna, nacionalna i međunarodna trgovina nedrvnim šumskim proizvodima može doprinijeti kućanstvima i zajednicama koje žive u ruralnim područjima, a time i ukupnoj ekonomiji zemlje. U toj konstelaciji izdvajaju se mala i srednja poduzeća koja, uz to što su nositelji gospodarskog razvoja svake zemlje, veliko značenje imaju u šumarstvu i djelatnostima koje se tiču uporabe nedrvnih šumskih proizvoda (NDŠP) u komercijalne svrhe. Poduzeća koja su bila predmet analize primarno su orijentirana na nekoliko kategorija proizvoda (ljekovito i aromatično bilje, gljve, med i šumsko voće). Istraživanjem je utvrđeno da ovisno o pojedinoj regiji, dominiraju poduzeća koja su usmjerena na određenu vrstu proizvoda. Tako, u klasteru 1 (Vojvodina) najbrojnija su poduzeća koja su usmjerena na ljekovito i aromatično bilje. U klasteru 2 (Južna i Istočna Srbija) su najbrojnija poduzeća usmjerena na šumsko voće, dok u klasteru 3 (Šumadija i Zapadna Srbija) poduzeća su u najvećoj mjeri usmjerena u ujednačenom omjeru na preradu i plasman gljiva i šumskog voća. Tržišni atraktivni proizvodi mogu predstavljati važno sredstvo za gospodarski rast i održivo gospodarenje šumama u lokalnim zajednicama. Međutim, malo je znanja o načinima njihovog sakupljanja, prerade i plasmana, unatoč velikim prirodnim potencijalima. U tom kontekstu bi i stanovnici ruralnih područja, kao i predstavnici malih i srednjih poduzeća trebali prepoznati tržišnu relevantnost ove kategorije proizvoda, posebno imajući u vidu da u najvećoj mjeri spadaju u domenu organske proizvodnje.

KLJUČNE RIJEČI: klaster analiza, nedrvni šumski proizvodi, prostorni raspored, Srbija, tržište 